\title{
Allergic reactions to genus Morus plants: a review
}

\author{
F. Papia', C. Incorvaia², L. Genovese ${ }^{3}$, S. Gangemi ${ }^{1}$ and P. L. Minciullo ${ }^{1 *}$ (i)
}

\begin{abstract}
Mulberry is a plant belonging to the family Moraceae, and genus Morus. Allergic sensitization to mulberries has been reported as both food allergy or respiratory allergy, and cross-reactivity between mulberries and other pollens or fruits was described. Clinically, in the articles reporting mulberry allergy, the reactions included respiratory allergy, airborne contact urticaria, anaphylaxis, oral allergy syndrome, and food induced urticaria. As far as cross-reactivity is concerned, the allergens identified thus far in mulberries include pathogenesis-related (PR)10 proteins, with sequence identity to Bet $v 1$ from birch, lipid transfer (LTP)1 proteins with identity with LTPs from Rosaceae family plants, panallergens groups, and also ubiquitin-like protein and cystatin-like protein. The two latter proteins account for cross-reactions with Parietaria judaica and Olea europaea. Such large cross-reactivity warrants to pay particular attention to the risk of systemic reactions to foods, particularly in subjects sensitized to birch, parietaria or olive pollens. In fact, the increasing use of mulberry as a food product, which is encouraged by its remarkable antioxidant power, expose sensitized patients to possible reactions after ingesting foods, dietary supplements or nutraceuticals containing mulberry. Mulberry allergenicity can vary according to the processing methods used since some allergens are thermostable and other loss their reactivity during heating.
\end{abstract}

Keywords: Moraceae, Morus, Mulberry, Cross-reactivity, Respiratory allergy, Food allergy

\section{Background}

Mulberry is a plant belonging to the family Moraceae, and genus Morus. Trees and shrubs of Moraceae are primarily tropical, with temperate trees represented by Morus (M), Broussonetia (B), and Maclura. There are 10 Morus species, with 3 native to North America, $M$. rubra, known as red mulberry, M. microphylla, known as Texas mulberry, and Maclura pomifera, also named Osage orange. Paper mulberry, B. papyrifera and white mulberry, M. alba, are native to Asia, where the latter is grown as food stock for silkworms [1].

Mulberry sensitization has been reported as both food allergy or respiratory allergy to mulberry pollens. There are also cases of cross-reactivity between mulberry and pollens or other fruits. Skin reactivity to red and white mulberries and to paper mulberry is usually strong; all three species have been implicated as local sources of pollinosis.

The aim of this study was to collect and review the published studies and cases of mulberry allergy and the cross-reactivity between mulberry and other allergen sources.

\section{Methodology}

We performed a Medline search, for English-language articles, published until October 2018, using the key words "mulberry" and "allergy". A second analysis was carried out using the species names of Moraceae family.

\footnotetext{
*Correspondence: pminciullo@unime.it

${ }^{1}$ Allergy and Clinical Immunology Unit, Department of Clinical and Experimental Medicine, University of Messina, 98125 Messina, Italy

Full list of author information is available at the end of the article
}

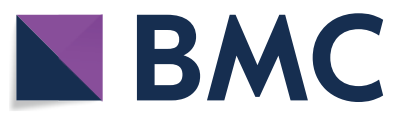

(c) The Author(s) 2020. This article is licensed under a Creative Commons Attribution 4.0 International License, which permits use, sharing, adaptation, distribution and reproduction in any medium or format, as long as you give appropriate credit to the original author(s) and the source, provide a link to the Creative Commons licence, and indicate if changes were made. The images or other third party material in this article are included in the article's Creative Commons licence, unless indicated otherwise in a credit line to the material. If material is not included in the article's Creative Commons licence and your intended use is not permitted by statutory regulation or exceeds the permitted use, you will need to obtain permission directly from the copyright holder. To view a copy of this licence, visit http://creativecommons.org/licenses/by/4.0/. The Creative Commons Public Domain Dedication waiver (http://creativecommons.org/publicdomain/zero/1.0/) applies to the data made available in this article, unless otherwise stated in a credit line to the data. 


\section{Clinical observations}

The Medline search identified 10 articles reporting mulberry allergy: 4 studies on respiratory allergy, 1 study on airborne contact urticaria, 2 on anaphylactic reaction, 2 on oral allergy syndrome, 1 on food induced urticaria. Table 1 shows the clinical characteristics of the cases reported.

\section{Respiratory pollen mediated reactions}

The first description dates back to 1971, when Targow [2] reported the impact of mulberry tree on respiratory allergy in South California. In Pakistan, paper mulberry pollen is a major cause of respiratory allergy, and is considered to be a high impact invader in this region [3]. Moreover, mulberry tree pollen is a major aeroallergen in northern regions of India and a predominant source of aeroallergens from January to April in Spain [4]. Exposure to pollen from white mulberry has been reported to cause asthma, allergic rhinitis, allergic conjunctivitis, and symptoms of contact urticaria in Spanish patients. Reports from Italy have also shown a case of pollinosis caused by Broussonetia papyrifera, a Chinese mulberry-tree, which is common in Northern Italy [5] and a sensitization to black mulberry fruit in a patient with respiratory allergy [6]. Sensitization to mulberry fruit, pollen and leaves has also been reported in the same patient [7].

\section{Food induced allergic reactions}

Two cases of anaphylactic reaction to mulberry fruit have been reported in patients with a history of respiratory allergy $[7,8]$.

Oral allergy syndrome have been reported, caused by ingestion of white mulberry [9] and jackfruit [10, 11], in patients with several sensitization to inhalant and other food allergens mostly belonging to Rosaceae family, as well as to fig, a fruit closely related to mulberry.

Moreover, a case of airborne contact urticaria due to white mulberry pollen was also described in a patient with respiratory symptoms. Mulberry airborne contact urticaria was suspected due to the negative patch test to fresh mulberry leaves, the absence of reactions harvesting the leaves outside the pollen season and the in vivo and in vitro sensitization to mulberry [12].

\section{Molecular components}

\section{Bet $v 1$ related allergens}

In 1997 in a patient with allergy to Morus alba pollen, leaf and fruit, two distinct proteins of $10 \mathrm{kDa}$ and $18 \mathrm{kDa}$ were detected in mulberry fruit; the first band was also present in apple and peach extracts and was not identified as profilin; the second was also detected in birch pollen, mulberry leaf and peach extracts [7].
In 2010 a $17 \mathrm{kDa}$ protein has been found in several Moraceae plants, such as fig, mulberry, jackfruit, with a homology of $60 \%, 56 \%$ and $76 \%$ respectively, to Bet v1 [13].

Previously, a $18 \mathrm{kDa}$ protein, called WAP18 (winter accumulating $18 \mathrm{kDa}$ protein) was identified in the cortical parenchyma cells of Morus bombycis tree; this protein showed high homology to other pathogenesis-related (PR)-10/bet v 1 proteins, such as Mal d 1, Bet v 1, Pru a 1 [14].

In 2014 a similar protein of $17 \mathrm{kDa}$ was detected in a patient with mulberry allergy, also sensitized to birch and with an oral allergy syndrome to peach, plum and apple; the same protein was found in another patient strongly sensitized to birch pollen, with specific IgE to mulberry fruit [8].

Allergy to jackfruit, a tropical fruit belonging to Moraceae family, can be included in birch pollen-related food allergies. In two patients sensitized to this fruit a similar $17 \mathrm{kDa}$ protein with cross reactivity to Bet $\mathrm{v} 1$ was detected [11], although a previous study showed no cross reaction between jackfruit and Bet $\mathrm{v} 1$ and Bet $\mathrm{v} 2$ [10].

\section{Ns-LTP}

Mor $\mathrm{n} 3$, the first allergen identified in the Morus genus by Ciardiello et al. is a $9 \mathrm{kDa}$ protein with high sequence identity with other nsLTP [15]. The highest sequence identity, with a rate of $75 \%$, was observed with Fra a 3, the strawberry nsLTP, followed by Pru p 3 (70\%), Mal d 3 (70\%), Cor a 8 (62\%), Art v 3 (61\%), Par j 2 (30\%). In vivo tests on ns-LTP allergic patients, mostly Pru $\mathrm{p} 3$ positive, showed a high rate of skin reactivity to Mor n 3 (88\%), even in subjects who have never ingested mulberry before.

Moreover, Mor $\mathrm{n} 3$ shows a strong cross-reactivity with other nsLTP; indeed, IgE inhibition test showed a complete inhibition to nArt $\mathrm{v} 3$ and Cor a 8 and a very high inhibition to nPru p 3 [15].

\section{Other allergens}

In Broussonetia papyrifera, also known as Chinese mulberry or paper mulberry, two pollen allergens, of $72 \mathrm{kDa}$ and $15 \mathrm{kDa}$ were identified [16]. Another study on paper mulberry pollen a $10 \mathrm{kDa}$ protein was reported as the major allergen, cross-reacting to white mulberry pollen; no identity with Bet $\mathrm{v} 1$ or nsLTP allergens was shown [17]. A recent study on Morus alba pollen reported a 14-15 kDa double band, identified as profilin and three new allergens: a nsLTP of $10 \mathrm{kDa}$ (nsLTP-10), a $8 \mathrm{kDa}$ ubiquitin like-protein and a $7 \mathrm{kDa}$ cystatin-like protein. Moreover, nsLTP-10 was found to cross-react with Par $j 1$ and Par $\mathrm{j} 2$ but not with Pru p 3. Immunoblotting-inhibition analysis revealed also a cross-reactivity between the 
Table 1 Clinical characteristics of mulberry allergy cases

\begin{tabular}{|c|c|c|c|}
\hline Authors & Sensitivities & Morus type sensitivity & Symptoms after mulberry contact \\
\hline Zanforlin [5] & $\begin{array}{l}\text { House dust mites } \\
\text { Cat epithelium }\end{array}$ & $\begin{array}{l}\text { Broussonetia papyrifera (China } \\
\text { mulberry pollen) }\end{array}$ & $\begin{array}{l}\text { Persistent rhinitis } \\
\text { Seasonal asthma }\end{array}$ \\
\hline Navarro [7] & $\begin{array}{l}\text { Alnus } \\
\text { Olea } \\
\text { Salsola } \\
\text { Chenopodium } \\
\text { Plantago } \\
\text { Apple } \\
\text { Peach } \\
\text { Cherry }\end{array}$ & $\begin{array}{l}\text { Morus alba pollen } \\
\text { Morus alba leaf } \\
\text { Morus alba fruit }\end{array}$ & $\begin{array}{l}\text { Rhinitis } \\
\text { Asthma (mulberry leaf) } \\
\text { Oral Allergy Syndrome (Rosaceae family) } \\
\text { Anaphylactic reaction (mulberry fruit) }\end{array}$ \\
\hline Choi [8] & $\begin{array}{l}\text { Alder } \\
\text { Birch } \\
\text { Hazel } \\
\text { Oak } \\
\text { House dust mites } \\
\text { Cat epithelium } \\
\text { Dog epithelium }\end{array}$ & Mulberry fruit (not specified) & $\begin{array}{l}\text { Rhinoconjunctivitis } \\
\text { Atopic dermatitis } \\
\text { Urticaria, chest tightness, breathing difficulty, oral swelling, nasal } \\
\text { obstruction (mulberry fruit) }\end{array}$ \\
\hline $\begin{array}{l}\text { Caiaffa [9] } \\
\text { Case } 1 \\
\text { Case } 2\end{array}$ & $\begin{array}{l}\text { Grass } \\
\text { Olive tree } \\
\text { Birch } \\
\text { Parietaria } \\
\text { Hazel } \\
\text { Dermatophagoides farinae } \\
\text { Fig } \\
\text { Hazelnut } \\
\text { Peanut } \\
\text { Bean } \\
\text { Pea } \\
\text { Soybean } \\
\text { Maize } \\
\text { Apple } \\
\text { Peach } \\
\text { Cherry } \\
\text { Melon } \\
\text { Tomato } \\
\text { Potato } \\
\text { Carrot } \\
\text { Celery } \\
\text { House dust mites } \\
\text { Parietaria } \\
\text { Olive tree } \\
\text { Peanut } \\
\text { Bean } \\
\text { Apple } \\
\text { Cherry } \\
\text { Plum } \\
\text { Strawbwrry } \\
\text { Orange } \\
\text { Fig }\end{array}$ & $\begin{array}{l}\text { Morus alba fruit } \\
\text { Morus alba pollen } \\
\text { Morus alba fruit }\end{array}$ & $\begin{array}{l}\text { Asthma, rhinitis } \\
\text { Lip and oropharyngeal angioedema, pruritus (mulberry) } \\
\text { Shortness of breath, lip, tongue and oropharyngeal swelling, pruritus } \\
\text { (fig) } \\
\text { Perennial rhinitis } \\
\text { Urticaria, generalized pruritus, abdominal pain (mulberry, fig) }\end{array}$ \\
\hline Wüthrich [10] & $\begin{array}{l}\text { Birch } \\
\text { Hazel } \\
\text { Beech } \\
\text { Grass mix } \\
\text { Mugworth pollen } \\
\text { Apple } \\
\text { Peach } \\
\text { Celery }\end{array}$ & Artocarpus integrifolia (jackfruit) & $\begin{array}{l}\text { Seasonal rhinoconjunctivitis and asthma } \\
\text { Oral allergy syndrome }\end{array}$ \\
\hline $\begin{array}{l}\text { Bolhaar [11] } \\
2 \text { Cases }\end{array}$ & $\begin{array}{l}\text { Birch } \\
\text { Grass } \\
\text { Apple } \\
\text { Hazelnut } \\
\text { Peach } \\
\text { Peanut }\end{array}$ & Artocarpus integrifolia (jackfruit) & $\begin{array}{l}\text { Rhinoconjunctivitis } \\
\text { Oral allergy syndrome, dyspnea, hoarseness (case 1) } \\
\text { Oral allergy syndrome, abdominal cramps (case 2) }\end{array}$ \\
\hline
\end{tabular}


Table 1 (continued)

\begin{tabular}{llll}
\hline Authors & Sensitivities & Morus type sensitivity & Symptoms after mulberry contact \\
\hline Munoz [12] & $\begin{array}{l}\text { Grass } \\
\text { House dust mite } \\
\text { Olive tree }\end{array}$ & Morus alba pollen & $\begin{array}{l}\text { Rhinoconjunctivitis, asthma } \\
\text { Erythema and edema of the hands and neck, lips and eyelids angi- } \\
\text { oedema, rhinitis and dyspnea (mulberry) }\end{array}$ \\
\hline
\end{tabular}

other two new allergens and protein present in Parietaria judaica and Olea europaea pollens [18].

\section{Discussion and conclusions}

Allergic reactions to mulberry have been frequently reported for many years. The allergic manifestations described above are quite varied and mainly include asthma or rhinitis induced by mulberry pollen while the reported episodes of anaphylaxis, food allergy and oral allergic syndrome are less frequent. Mulberry pollen has to be considered an important respiratory allergen in many areas. This has led to great attention in certain areas such as US, Spain or Asia versus mulberry pollen due to the numerous cases of rhinitis or asthma. Several studies have analyzed the possible cross reactivity between mulberry and other pollens or fruits, with slightly discordant results. In fact, Navarro [7] first hypothesized a possible correlation between mulberry allergen and birch, in particular with Bet $\mathrm{v}$ 1. Later, a mulberry allergen of $17 \mathrm{kDa}$, the same weight of PR10 protein, with sequence identity to Bet v 1.

Another allergen identified, Mor $\mathrm{n}$ 3, is a nsLTP1, cross-reacting with other nsLTP.

Other allergens cross-react with Parietaria judaica and Olea europaea.

The identification of these new mulberry allergens is of considerable importance. In fact, even in areas where mulberry tree is uncommon, there may be cases of mulberry reaction due to cross reactivity with Bet v1, $P$. judaica or O. europaea. Although the most reported reactions are caused by mulberry pollen, it cannot be excluded that mulberry ingestion can cause a reaction due to crossreactivity with other pollen allergens.

Nowadays mulberry is used not only as fresh fruit, but also food products and for therapeutic purpose, due to the antioxidant effects of phenolic compounds, flavonoids and anthocyanins. Therefore, mulberry leaves and fruits are used for they immunomodulatory and antiinflammatory effects, antibacterial activity and hepatoprotective and cardioprotective functions, for the treatment and prevention of several conditions such as diabetes mellitus, obesity, atherosclerosis, inflammation $[19,20]$.

Mulberry processing for extract production causes the loss of polyphenols, anthocyanins, and antioxidant capacity [21]; therefore, optimization of food processing aimed to preserve the beneficial effects could improve the quality of the final product. In this context, an alternative to conventional thermal processing, as high hydrostatic pressure method has shown to minimize antioxidant loss [22].

Even food allergenicity and immunoreactivity can change during processing, particularly during heating. It is know that thermal processing decreases PR-10 proteins allergenicity; on the contrary nsLTP and seed storage proteins have heat-stable allergens [23]. Therefore, although during thermal processing some mulberry allergens can loss their reactivity, nsLTP allergenicity can remain. Moreover, the search of alternative processing methods to avoid antioxidant loss during heating, can lead to the persistence of immunoreactivity of thermo-labile allergens.

In conclusion, based on the currently common use of mulberry as a food product, possible reactions after ingesting foods, dietary supplements or nutraceuticals containing mulberry, in subjects sensitized to birch, parietaria or olive pollens, must be taken into account. Moreover, better information on the role of processing methods on the allergenicity can help, in the future, to develop mulberry products with low allergenic potency.

\section{Acknowledgements}

None.

\section{Authors' contributions}

PF and IC conception and design of the study. GL and SG analysis and interpretation of patient data, PLM: revision of the literature. All authors read and approved the final manuscript.

\section{Funding}

This work did not receive any specific grant from funding agents in the public, commercial or not-for-profit sectors.

Availability of data and materials

Data and materials presented are available in the manuscript and are stored in the Allergy and Clinical Immunology Division at University Hospital of Messina.

Ethics approval and consent to participate

Not applicable.

\section{Consent for publication \\ Not applicable.}

Competing interests

The authors declare that they have no competing interests.

\section{Author details}

${ }^{1}$ Allergy and Clinical Immunology Unit, Department of Clinical and Experimental Medicine, University of Messina, 98125 Messina, Italy. ${ }^{2}$ Cardiac/ 
Pulmonary Rehabilitation, ASST Pini/CTO, Milan, Italy. ${ }^{3}$ Istituto per le Risorse Biologiche e le Biotecnologie Marine (IRBIM) CNR Messina, Messina, Italy.

Received: 25 July 2019 Accepted: 8 February 2020

Published online: 19 February 2020

\section{References}

1. Weber RW. Red mulberry. Ann Allergy Asthma Immunol. 2003;90(5):A6.

2. Targow AM. The mulberry tree: a neglected factor in respiratory allergy in Southern California. Ann Allergy. 1971;29:318-22.

3. Pallewatta N, Reaser JK, Gutiérrez AT, editors. Invasive alien species in South-Southeast Asia: National reports \& directory of resources. Cape Town: Global invasive species programme; 2003.

4. Subiza J, Jerez M, Jimenez JA, Narganes MJ, Cabrera M, Varela S, et al. Allergenic pollen and pollinosis in Madrid. J Allergy Clin Immunol. 1995;96:15-23.

5. Zanforlin M, Incorvaia C. A case of pollinosis to Broussonetia papyrifera. Allergy. 2004;59:1136-7.

6. Romano C, Ferrara A, Falagiani P. A case of allergy to globe artichoke and other clinical cases of rare food allergy. J Investig Allergol Clin Immunol. 2000;10:102-4.

7. Navarro AM, Orta JC, Sánchez MC, Delgado J, Barber D, Lombardero M. Primary sensitization to Morus alba. Allergy. 1997;52:1144-5.

8. Choi JH, Sim JK, Oh JY, Hur GY, Min KH, Lee SY, et al. An IgE-mediated allergic reaction caused by mulberry fruit. Allergy Asthma Immunol Res. 2015:7:195-8.

9. Caiaffa MF, Cataldo VM, Tursi A, Macchia L. Fig and mulberry cross-allergy. Ann Allergy Asthma Immunol. 2003;91:493-5.

10. Wüthrich B, Borga A, Yman L. Oral allergy syndrome to jackfruit (Artocarpus integrifolia). Allergy. 1997;52(4):428-31.

11. Bolhaar ST, Ree R, Bruijnzeel-Koomen CA, Knulst AC, Zuidmeer L. Allergy to jackfruit: a novel example of Bet v 1-related food allergy. Allergy. 2004:59:1187-92.

12. Muñoz FJ, Delgado J, Palma JL, Giménez MJ, Monteseirín FJ, Conde J. Airborne contact urticaria due to mulberry (Morus alba) pollen. Contact Dermat. 1995;32:61.

13. Hemmer W, Focke M, Marzban G, Swoboda I, Jarisch R, Laimer M. Identification of Bet v 1-related allergens in fig and other Moraceae fruits. Clin Exp Allergy. 2010;40:679-87.
14. Ukaji N, Kuwabara C, Takezawa D, Arakawa K, Fujikawa S. Accumulation of pathogenesis related (PR) 10/Bet $v 1$ protein homologues in mulberry (Morus bobycis Koidz.) tree during winter. Plant Cell Environ. 2004;27:1112-21.

15. Ciardiello MA, Palazzo P, Bernardi ML, Carratore V, Giangrieco I, Longo $V$, et al. Biochemical, immunological and clinical characterization of a cross-reactive nonspecific lipid transfer protein 1 from mulberry. Allergy. 2010;65:597-605.

16. Chen Z, Zhu N, Chen X, Yang Y, Li Y, Wu Z, et al. Purification and identification of $72 \mathrm{kDa}$ and $15 \mathrm{kDa}$ allergens from Broussonetia papyrifera pollen. Iran J Allergy Asthma Immunol. 2013;12:312-20.

17. Micheal S, Wangorsch A, Wolfheimer S, Foetisch K, Minhas K, Scheurer $S$, et al. Immunoglobulin E reactivity and allergenic potency of Morus papyrifera (paper mulberry) pollen. J Investig Allergol Clin Immunol. 2013;23:168-75.

18. El-Qutob D, Bartolome B, Cuesta J, Mir A, Alberola A, Pastor-Vargas C. Identification of a lipid transfer protein as a new allergen from Morus alba pollen. J Investig Allergol Clin Immunol. 2017;27:263-5.

19. Chan EW, Lye PY, Wong SK. Phytochemistry, pharmacology, and clinical trials of Morus alba. Chin J Nat Med. 2016:14:17-30.

20. Rodrigues EL, Marcelino G, Silva GT, Figueiredo PS, Garcez WS, Corsino $J$, et al. Nutraceutical and medicinal potential of the Morus species in metabolic dysfunctions. Int J Mol Sci. 2019;20:301.

21. Tomas M, Toydemir G, Boyacioglu D, Hall RD, Beekwilder J, Capanoglu E. Processing black mulberry into jam: effects on antioxidant potential and in vitro bioaccessibility. J Sci Food Agric. 2017;97:3106-13.

22. Wang F, Du BL, Cui ZW, Xu LP, Li CY. Effects of high hydrostatic pressure and thermal processing on bioactive compounds, antioxidant activity, and volatile profile of mulberry juice. Food Sci Technol Int. 2017;23:119-27.

23. Masthoff $L J$, Hoff R, Verhoeckx $K C$, van Os-Medendorp $H$, MichelsenHuisman A, Baumert JL, et al. A systematic review of the effect of thermal processing on the allergenicity of tree nuts. Allergy. 2013;68:983-93.

\section{Publisher's Note}

Springer Nature remains neutral with regard to jurisdictional claims in published maps and institutional affiliations.
Ready to submit your research? Choose BMC and benefit from:

- fast, convenient online submission

- thorough peer review by experienced researchers in your field

- rapid publication on acceptance

- support for research data, including large and complex data types

- gold Open Access which fosters wider collaboration and increased citations

- maximum visibility for your research: over $100 \mathrm{M}$ website views per year

At BMC, research is always in progress.

Learn more biomedcentral.com/submissions 